IRA-International Journal of Management \& Social Sciences

ISSN 2455-2267; Vol.06, Issue 02 (2017)

Pg. no. 235-252

Institute of Research Advances

http://research-advances.org/index.php/RAJMSS

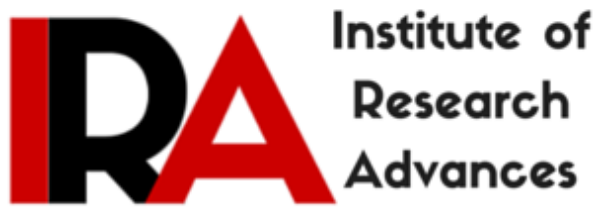

\title{
Determinants of Stores Choice in Rural Markets: An Empirical Study in Karnataka State
}

\author{
${ }^{1}$ Dr. S. Sathyanarayana \& ${ }^{2}$ Prof. Sudhindra Gargesha \\ ${ }^{1}$ Associate Professor, MP Birla Institute of Management, Bangalore, India. \\ ${ }^{2}$ Joint Director, MP Birla Institute of Management, Bangalore, India.
}

Type of Review: Peer Reviewed.

DOI: http://dx.doi.org/10.21013/jmss.v6.n2.p7

\section{How to cite this paper:}

Sathyanarayana, S., \& Gargesha, S. (2017). Determinants of Stores Choice in Rural Markets: An Empirical Study in Karnataka State. IRA-International Journal of Management \& Social Sciences (ISSN 2455-2267), 6(2), 235-252. doi:http://dx.doi.org/10.21013/jmss.v6.n2.p7

(C) Institute of Research Advances

(cc) EY-NC

This work is licensed under a Creative Commons Attribution-Non Commercial 4.0 International License subject to proper citation to the publication source of the work.

Disclaimer: The scholarly papers as reviewed and published by the Institute of Research Advances (IRA) are the views and opinions of their respective authors and are not the views or opinions of the IRA. The IRA disclaims of any harm or loss caused due to the published content to any party. 


\begin{abstract}
The current empirical study entitled "determinants of stores choice in rural markets: an empirical study in Karnataka state" has been undertaken with an intention to investigate the stores' loyalty of the rural consumers and the major factors that determine the preference of a particular retail outlet. To realise the stated objectives the researchers have employed a survey method. A structured questionnaire was used for the collection of the data from 1,600 rural respondents. The validity of the research instrument was adjudged using Cronbach's coefficient $(\alpha)$ and was calculated to test the reliability and internal consistency of the responses. The collected data was tested for the normality and various statistical tools have been employed to analyse the collected data. Based on the analysis of the study a brief summary of findings have been made and a meaningful conclusion has been drawn. Finally the results have been compared with the possible evidence. The study revealed that majority of the rural consumer respondents purchase their entire FMCG requirement in one shop and majority of the rural consumers seek clarification (case-on-case basis) from the retailer before purchasing the product. We found a significant difference in the nature of clarification made by the rural consumer to the retailer. There is a significant influence of the distance to the nearest town of the rural consumer and the passing of benefits by the retailer to the rural consumers and there is a significant relationship in the reasons offered by occasional and consistent categories of retailers who do not pass benefits to rural consumers.
\end{abstract}

Keywords: Rural Consumers, Stores Choice, Credit Facilities, Remoteness, Brand Image

\title{
I. INTRODUCTION
}

RinkuPegu (1999) in her research based article raised a million dollar question to marketers that, what has made the rural consumers so attractive to Indian companies now? To begin with, the size of the rural market (Richa Mishra (2003)) over 70\% of India's population lives in around 627,000 villages in rural areas. In terms of population, Indian rural market is almost twice as large as the entire market of the U.S.A. or the erstwhile U.S.S.R. The annual size of the rural market, in terms of value, is currently estimated at around Rs 5,000 crore for durables, Rs. 45, 000 crore for agri-inputs and implements (almost 100 percent) and yet, another Rs 8,000 crore for automobiles (Kashyap 2003). Not just the rural population is numerically large; there has also been a phenomenal improvement in rural incomes as well as their spending power. There by the rural market is assumed to be of much importance due to the rapid prosperity, especially from the last decade (Das and Sen 1991). The rate of growth of the rural market segment is however not the only factor that has driven marketers to go rural. The other compelling factor is the fact that the urban markets are becoming increasingly complex, competitive and saturated (2004); (Rinku Pegu 1999). This has led FMCG companies to turn towards rural areas in order to sustain their revenue growth and profitability(2004); (Shashidhar 2003). The policies of the government largely favour rural development programmes.

The biggest mistake a FMCG marketer can make while entering the rural market is to treat it as an extension to the existing urban market. Almost all the rural marketing strategies have enjoyed an urban lifestyle and can more easily connect to the urban mindset. But the whole issue is that there is a vast difference in the lifestyle of the rural and urban consumers (Das and Sen 1991); (Richa Mishra 2003); (Kamath and Moorthy 2003) and (2001). The difference is not only between urban and rural but also with in the rural areas. Banerjee (2002) suggested that the marketers should have two different mindsets while offering products or services - one is an urban mindset and other being rural mindset and marketers should offer appropriate goods and services according to these two divergent mindsets.

For the successful exploitation of rural markets, an adequate infrastructure is a basic prerequisite. The absence of such a satisfactory infrastructure in Indian conditions has been a major hurdle for the marketer's efforts in entering the rural markets. In the words of Hollander (1960), the chief role of marketing channels is to convert potential buyers into profitable customers. Due to the vastness of the rural markets and scattered character of their location, the choice of distributive 
channels have a great bearing on the quality of service to the customer and its selling cost. It may be pointed out that if the existing channels do not respond adequately, efforts should be made to device new channels of distribution in order to ensure that consumer products of all kinds are made available in rural areas (NavinMathur 1981).

\section{LITERATURE REVIEW}

Store choice is classified in literature as primarily a cognitive process. Store choice behaviour of the shoppers has been found to be similar to brand choice. The only difference here is being the importance of the spatial dimension. While the brand choice is devoid of any geography, the choice of a store is very much influenced by location especially in the context of FMCGs (Fotheringham, 1998). In a study store choice of behaviour among audio equipment shoppers, Dash, Schiffman and Berenson (1976) found that the level of pre-purchase information regarding the brand determined the type of store chosen. Shoppers who had higher level of pre-purchase information generally shopped at the speciality store, whereas the shopper with low pre-purchase information bought at departmental stores. A store is chosen based on the self-confidence that the customer has regarding the store about the nature, quality of product and service he would receive. The importance placed on the customer's familiarity with the store will depend upon the perceived risk in making an erroneous purchase and the importance of the product category of the shopper.

As an extension of the above study, the store choice problem has also been studied using the framework of diffusion of innovation propounded by Cunningham (Hisrich, Dornoff and Kernan, 1972).

In an early article, Dodge and Summer (1969) found store choice to be dependent on socioeconomic background of consumers, their personality and past purchase experience. Lumpkin, Greenberg and Goldstuckers (1985) found that elderly customers behave differently from younger ones in terms of the type of store that is patronized. The former group is less price conscious and proximity of residence to store is not an important factor. They consider shopping as recreational activity and thus chose a store that has a high perceived "entertainment" value.

In recent times, Leszczyc, Sinha and Timmermans (2000) indicate that store choice is a dynamic decision and can be conceptualised as a problem of deciding when and where to shop. Store choice is dependent on the timing of shopping trips as consumers may go to a local store for short 'fill-in' trips and go to a more distant grocery store for regular shopping trips (Kahn and Schmittlein, 1989). Both these decisions are influenced by shopper characteristics and consumption patterns (Leszczyc, Sinha and Timmermans, 2000). The choice of a store is affected by the brand being bought as well as the personal values that the shopper cherishes (Erdem, Oumlil and Tuncalp, 1999). Hence, a shopper with high personal gratification value would attach more importance to store status than a self-reliant intellectual type shopper. The concept of positioning of stores has been captured in marketing literature in the last decade (Woodside and Trappey, 1992). This study finds that shoppers look for and develop "hot buttons" that help in choosing among stores (Woodside and Trappey, 1992).

Kenhove, Wulf and Waterschoot (1999) studied that the store choice decision across various tasks like urgent purchase, large quantities, difficult job, regular purchase and got ideas. The chosen stores differ in their salience rating depending on the task the shopper has intended to perform, where it is found that stores are affected by situational factors. In a study conducted by Mattson (1982), it was found that situational attributes, such as time pressure and gift-versus self-shopping, can influence store choice and attribute salience. It is also indicated that the situational influence needs to be evaluated for every visit and hence some shoppers may change their choice because of situation specific drivers.

The consumption patterns are different in rural areas as compared to the urban. The occupation of the consumers in rural areas includes farming, agriculture, small businesses like retail shops, and employment in government as well as private sectors. 
In an empirical study by study by Sathyanarayana S. (2014) found that, rural retailers generally pushes spurious products because of high margin and the availability of credit facilities from the suppliers of the spurious products.

In a study conducted by Satish Rewatkar concluded that the occupation of the rural consumers shares a significant relationship with purchasing of branded fast moving consumer goods.

Surajit Dey et al. (2012) conducted an empirical study with an objective to explore the potential of rural retail market of India, accessing their needs for products and brands. In their study they found that most of the respondents agreed that the products of their choice are not available in the existing retail outlets. Therefore, they were forced to go for available substitutes.

In an empirical study by Adelina \& Eric Calderwood, (2002) using a longitudinal research methodology to investigate the grocery shopping habits of residents in rural communities in Western Stirlingshire, Scotland. Findings revealed that although respondents held a positive overall view of their local shops, less than one third purchased a high proportion of their food shopping in local shops.

In a study conducted by Devadas and Manohar (2010) concluded that the urban- rural inequality in market, as well as customer characteristics bring a major difference in shopping behavior and consumption pattern of the two communities.

In a study by Sathyanarayana \&Ramani Ganesh (2008) suggested the marketers to make use of over 2.5 million kiranas throughout India's rural towns and villages. In order to reach these local shops and establish a brand presence in them, companies need substantial amounts of working capital and a large committed sales force. The rural customer generally goes to the same retailer to buy goods. Naturally there's a very strong bonding in terms of trust between the two. Also with the low education levels of rural sector the rural buying behavior is such that the consumer doesn't ask for the things explicitly by brand but like "laal wala sabun dena" or "paanch rupey waali chai dena". Now in such a scenario the brand becomes subservient to the retailer and he pushes whatever brand fetches him the greatest returns. Thus, as there is a need to understand the rural consumer, similarly need is there to study the retailer, as he is a chief influencer in the buying decision.

The objective of the current empirical study is to identify, the key determinants of retail stores choice in rural areas and to offer suggestions to the marketers of FMCG to develop strategies to cater to the needs of the rural consumers. The review of previous literature on rural marketing, thus throws light on facts relating to the gap in the study of the chosen subject. Most studies have been retrospective, and have neglected to collect the first hand information from rural respondents. Majority of the studies covered only a few aspects of the rural market. With this knowledge, it is assumed that the present work would make an addition to existing works on rural marketing by collecting firsthand information from the rural respondents with respect to their stores choice. The structure of the present study is as follows. Section two discusses the review of previous literature relating to the topic. Section three outlines a brief discussion about the objectives of the study, the research design and the methodology of the study. Section four deals with the analysis and inference of the data collected through a structured instrument and in the final section a brief summary of findings, discussion and conclusion has been drawn and the findings of the study are compared with the possible evidence.

\section{RESEARCH DESIGN}

\section{OBJECTIVES OF THE STUDY}

The following are the main objectives of the study, which the researcher wishes to enquire and understand in the process of this study.

1. To know the stores' loyalty of the rural consumers;

2. To identify the major factors that determine the preference of a particular retail outlet by the rural consumers; 
3. To investigate any suggestions sought by the rural consumers from the retailers before buying FMCG;

4. To investigate the credit facilities extended by the retailers to rural consumers;

5. To find out whether the rural retailer transfers benefits offered by marketers to the rural consumers and

6. To investigate the availability of the FMCG at MRP quoted on the pack to the rural consumers.

\section{HYPOTHESIS OF THE STUDY}

H0: There is no significant difference in the factors among the rural consumers that lead to the preference of a particular retail outlet.

H0: There is no significant influence distance to the nearest town for the rural consumer on the rural consumer purchasing the entire FMCG requirement in same shop.

H0: There is no significant influence of annual house hold income on the rural consumers purchasing the entire FMCG requirements in the same shop.

H0: There is no significant difference in the nature of clarification made by the rural consumers to the retailer.

H0: There is no significant influence of the distance to the nearest town of the rural consumer and the passing of benefits by the retailer to the rural consumers.

H0: There is no significant relationship in the reasons offered by occasional and consistent categories of retailers who do not pass benefits to rural consumers.

H0: There is no significant influence of distance to the nearest town (remoteness) on purchase of FMCG by the rural consumer respondents at MRP quoted.

\section{RESEARCH METHODOLOGY NATURE OF STUDY}

The study is exploratory in nature as it endeavors to uncover the latent behavioural aspects of rural consumers and retailers in the state of Karnataka.

\section{UNIVERSE OF STUDY AND POPULATION}

The universe of the study is rural consumers in the rural villages of Karnataka situated in India. The universe of the study is classified as North Karnataka, South Karnataka, East Karnataka and West Karnataka. The study is based on the empirical survey of 200 villages situated in the state of Karnataka. An index of various districts, taluqas and villages was created to classify them into homogeneous groups (based on census 2001 reports).

\section{PRIMARY DATA SOURCE}

Firsthand information was obtained from respondents through a structured questionnaire. An interview schedule was constructed to elicit information from the respondents. The researcher chose an interview schedule since the respondent has to be coaxed to answer the questions put forth in the questionnaire. Moreover the researcher had a stringent requirement for the data to be pure and in all senses comprehend the very spirit of the questionnaire and thus the research. The researcher could also clarify any doubts to the respondent and explain the objective of each question whenever the respondent raised doubts. The questionnaire contained different sections and each section concentrated on particular aspect of the retailing and buying and consumer behavior. The questions were both open ended and close ended. In close ended, questions consisted of dichotomous, multiple choice and rating scales, to elicit the respondents' association with the question posed. Before scaling for full research, the researcher initiated a pilot study with 100 rural consumers. These collected questionnaires were analysed to determine whether the data collected helps the researcher to fulfill the objectives of the study, apart from testing the validity of the questions put across to the respondents. 
The validity of the questionnaire was adjudged, using Cronbach's coefficient $(\alpha)$ was calculated to test the reliability and internal consistency of the responses. Cronbach's coefficient, having a value of more than 0.7 is considered adequate for such exploratory work. The values of $\alpha$ in this study for the reported questions were found to be $0.736,0.805,0.765$ etc. giving an average value of 0.768 . It implies that there is a high degree of internal consistency in the responses to the questionnaire.

\section{SAMPLE SIZE}

The researcher has arrived at a sample size of 1600 for rural consumer respondents from among four zones of Karnataka state comprising approximately 200 accessible villages.

\section{ANALYTICAL METHOD}

The data collected is initially organized in a meaningful manner with the help of software. Once organized, the researcher tabulated the frequencies, which provided the requisite profile of the data collected and helped the researcher build the contingency tables for further detailed analysis. On performing detailed analysis, patterns from the data is further put for validation through testing of hypothesis, wherever the researcher deemed important and based on the conditions set for such test. Based on that a brief summary of findings have been made and a meaningful conclusion have been drawn. Finally the results were compared with the possible evidence.

\section{DATA ANALYSIS}

TABLE No. 4.1: STORE LOYALTY OF THE RURAL CONSUMER RESPONDENTS

\begin{tabular}{|l|r|r|}
\hline & Frequency & Percent \\
\hline Always & 1099 & 68.69 \\
\hline Mostly & 451 & 28.19 \\
\hline Sometimes & 22 & 1.38 \\
\hline Rarely & 19 & 1.18 \\
\hline Never & 09 & 0.56 \\
\hline Total & 1600 & 100.0 \\
\hline
\end{tabular}

\section{Inference:}

The intention of the researcher is to understand whether the rural consumer respondents shop for FMCG in the same shop. The idea is to understand the stores loyalty of the rural consumers. The researchers have used a five-point scale to gauge the response starting from a positive scale of always and ending with a negative scale of never. $68.69 \%$ of the rural consumers indicate that they wanted to buy FMCG from the same retail outlet, followed by $28.19 \%$ of the rural consumers indicating that they buy their FMCG requirement mostly from the same shop, $1.38 \%$ indicating that generally they buy their requirement from the same shop, $1.18 \%$ rarelyfrom the same shop and $0.56 \%$ indicate that they do not depend on the same shop for their shopping requirement of FMCG purchases.

TABLE No. 4.2: ADEQUACY OF FRESH STOCK AT THE PREFERRED STORE OR RETAIL OUTLET

\begin{tabular}{|l|r|r|}
\hline & Frequency & Percent \\
\hline Always & 400 & 25.0 \\
\hline Mostly & 520 & 32.5 \\
\hline Sometimes & 272 & 17.0 \\
\hline Rarely & 392 & 24.5 \\
\hline Never & 16 & 1.0 \\
\hline Total & 1600 & 100.0 \\
\hline
\end{tabular}

Source: Field survey 


\section{Inference:}

The intention of the researcher in constructing Table 4.2 is to understand the availability of fresh stocks among rural retailers and / or the place at which the rural consumer shops. The researcher has used a five-point scale to gauge the response starting from a positive scale of always and ending with a negative scale of never. $32.5 \%$ of the rural consumers indicate that the retail outlet where they shop is able to meet mostly their requirement in terms of providing fresh stock, followed by $25 \%$ of the rural consumers indicating that they always get fresh stock, $24.5 \%$ indicating they rarely get fresh stocks and $17 \%$ indicating that they are able to get fresh stock only sometimes. Only $1 \%$ of the rural consumers indicate that they never get fresh stock in the retail outlet they shop.

\section{RANKING OF INFLUENTIAL FACTORS THAT DETERMINING THE PREFERENCE OF A PARTICULAR RETAIL OUTLET}

\section{Inference:}

The intention of the researcher in framing this question is to understand the perspective of the rural consumer respondents on the factors of influence in their preference for a particular outlet where they shop. The researcher from preliminary study of the rural consumers have understood the importance of the following factors, viz - credit facilities, reasonable price, personal rapport with the retailers, good service, nearness and other factors pertaining to the outlet, which influence the rural consumers preference. Of the respondents, who answered to this query of the researcher, 38.5\% indicated that the predominant factor being provision of credit facilities (very peculiar to rural marketing), 33\% indicating personal rapport with the shop keeper (rank 2), 16\% indicating reasonable price (rank 3 ), $36.5 \%$ indicating availability of good service (rank 4), $40 \%$ indicating proximity of the retail outlet (rank 5) and $73.5 \%$ indicating the last factor they consider is other factors pertaining to the shop which is not covered in the previous categories of factors.

\section{TABLE No. 4.3: TEST OF SIGNIFICANCE: DISTANCE TO THE NEAREST TOWN (REMOTENESS) ON PREFERENCE OF A PARTICULAR RETAIL OUTLET}

The intention of the researcher here is to understand the influence of variable, distance to the nearest town for the rural consumer in purchasing all FMCG requirements from the same shop. To understand the significance, the researcher constructed the following hypothesis and used a Pearson Chi-Square test to prove or disprove the hypothesis.

H0: There is no significant influence distance to the nearest town for the rural consumer on the rural consumer purchasing the entire FMCG requirement in same shop.

Pearson Chi-Square Tests

\begin{tabular}{|l|l|r|}
\hline \multicolumn{2}{|l|}{} & $\begin{array}{l}\text { Do you always buy your FMCG } \\
\text { requirement in the same shop? }\end{array}$ \\
\hline \multirow{2}{*}{ Distance to the nearest town } & Chi-square & 25.809 \\
\cline { 2 - 3 } & df & 3 \\
\cline { 2 - 3 } & Sig. & .000 \\
\hline
\end{tabular}

\section{Result:}

Since the tabulated value of $\chi^{2}$ is 25.809 with 3 degrees of freedom with a significance level of 0.000 which is lesser than the set significance of 0.05 (95\% confidence limit) for tabulated relationship. Therefore, we can reject the null hypothesis.

\section{TABLE No. 4.4: TEST OF SIGNIFICANCE: ANNUAL HOUSEHOLD INCOME OF THE RESPONDENTSON PREFERENCE OF A PARTICULAR RETAIL OUTLET}

The intention of the researcher here is to understand the influence of variable, annual household income of the rural consumer in purchasing all FMCG requirements from the same shop. To 
understand the significance, the researcher constructed the following hypothesis and used a Pearson Chi-Square test to prove or disprove the hypothesis.

H0: There is no significant influence of annual house hold income on the rural consumers purchasing the entire FMCG requirements in the same shop.

Pearson Chi-Square Tests

\begin{tabular}{|l|l|r|}
\hline \multicolumn{2}{|l|}{} & \multicolumn{2}{|c|}{$\begin{array}{c}\text { Do you always buy your } \\
\text { FMCG requirement in the same } \\
\text { shop? }\end{array}$} \\
\hline Annual House Hold Income & Chi-square & 57.998 \\
\cline { 2 - 3 } & df & 3 \\
\cline { 2 - 3 } & Sig. & .000 \\
\hline
\end{tabular}

Result:

Since the tabulated value of $\chi^{2}$ is 57.998 with 3 degrees of freedom with a significance level of 0.000 which is lesser than the set significance of 0.05 (95\% confidence limit) for tabulated relationship. Therefore, we can reject the null hypothesis.

TABLE No. 4.5: SUGGESTIONS SOUGHT BY THE RESPONDENTS FROM THE RETAILER BEFORE BUYING FMCG

\begin{tabular}{|c|c|c|c|c|c|c|}
\hline & & \multicolumn{3}{|c|}{ Frequency } & \multicolumn{2}{|r|}{ Percent } \\
\hline \multicolumn{2}{|l|}{ No } & \multicolumn{3}{|r|}{416} & \multicolumn{2}{|r|}{26.0} \\
\hline \multicolumn{2}{|l|}{ Yes } & \multicolumn{3}{|r|}{128} & \multicolumn{2}{|r|}{8.0} \\
\hline \multicolumn{2}{|l|}{ Sometimes } & \multicolumn{3}{|c|}{1056} & \multicolumn{2}{|r|}{66.0} \\
\hline \multicolumn{2}{|l|}{ Total } & \multicolumn{3}{|c|}{1600} & \multicolumn{2}{|r|}{100.0} \\
\hline \multicolumn{7}{|c|}{ NATURE OF SUGGESTIONS } \\
\hline & \multicolumn{2}{|c|}{ Regarding quality } & \multicolumn{2}{|c|}{$\begin{array}{c}\text { Regarding the } \\
\text { suitability to the need }\end{array}$} & \multicolumn{2}{|c|}{ Brand Image } \\
\hline & $\mathbf{F}$ & $\%$ & $\mathbf{F}$ & $\%$ & $\mathbf{F}$ & $\%$ \\
\hline No & 208 & 13.0 & 656 & 41.0 & 928 & 58.0 \\
\hline Yes & 976 & 61.0 & 528 & 33.0 & 256 & 16.0 \\
\hline \multirow[t]{3}{*}{ Total } & 1184 & 74.0 & 1184 & 74.0 & 1184 & 74.0 \\
\hline & \multicolumn{2}{|c|}{ Price } & \multicolumn{2}{|c|}{ Special Offer } & \multicolumn{2}{|c|}{$\begin{array}{c}\text { While shifting the } \\
\text { brand }\end{array}$} \\
\hline & $\mathbf{F}$ & $\%$ & $\mathbf{F}$ & $\%$ & $\mathbf{F}$ & $\%$ \\
\hline No & 544 & 34.0 & 472 & 29.5 & 840 & 52.5 \\
\hline Yes & 640 & 40.0 & 712 & 44.5 & 344 & 21.5 \\
\hline \multirow[t]{3}{*}{ Total } & 1184 & 74.0 & 1184 & 74.0 & 1184 & 74.0 \\
\hline & \multicolumn{2}{|c|}{$\begin{array}{l}\text { Regarding the } \\
\text { usability }\end{array}$} & \multicolumn{2}{|c|}{ Spurious Products } & & \\
\hline & $\mathbf{F}$ & $\%$ & $\mathbf{F}$ & $\%$ & & \\
\hline$\overline{\mathrm{No}}$ & 848 & 53.0 & 952 & 59.5 & & \\
\hline Yes & 336 & 21.0 & 232 & 14.5 & & \\
\hline Total & 1184 & 74.0 & 1184 & 74.0 & & \\
\hline
\end{tabular}

Source: Field survey

Inference: The intention of the researcher is to understand the suggestions seeking nature of the rural consumers. This suggestion seeking nature will help the company salesman or the retailer to swing the purchase decision of rural consumers in their product's favour. $66 \%$ of the rural consumers indicate that they sometimes seek clarification (case-on-case basis) from the retailer before purchasing the product, $8 \%$ indicate that they always clarify before purchasing from the rural consumer and $26 \%$ 
indicate that they decide the product or brand they want to buy, have a complete idea before they buy and hence do not seek suggestions from the retailer.

The intention of the researcher in constructing this question is to understand the nature of suggestion the rural consumers seek before the purchases of the product. From preliminary study, the researcher has understood that the following are areas that a consumer clarifies from the retailers, viz - regarding quality, suitability to the consumers need, brand image, price, special offers, for switching brands, regarding usability and check the product is spurious or not. From above table it is evident that the rural consumers prime clarification and suggestion is with respect to quality of the product with a responses amounting to $61 \%, 44.5 \%$ indicating their clarification regarding special offers, $40 \%$ indicating price, $33 \%$ indicating suitability of the need of the product, $21.5 \%$ indicating clarification that arise while switching brands and $21 \%$ indicating the usability nature of the product based clarification.

TABLE No. 4.6

\begin{tabular}{|c|c|c|c|c|c|c|}
\hline \multicolumn{7}{|c|}{ RESPONDENTS AVAILING CREDIT FACILITIES FROM THE RETAILERS } \\
\hline & & \multicolumn{3}{|c|}{ Frequency } & \multicolumn{2}{|r|}{ Percent } \\
\hline \multicolumn{2}{|l|}{ No } & & & 424 & & 26.5 \\
\hline \multicolumn{2}{|l|}{ Yes } & & & 880 & & 55.0 \\
\hline \multicolumn{2}{|l|}{ Sometimes } & & & 296 & & 18.5 \\
\hline \multicolumn{2}{|l|}{ Total } & & & 1600 & & 100.0 \\
\hline \multicolumn{7}{|c|}{$\begin{array}{l}\text { EXTENT OF CREDIT AVAILED FROM THE RETAILERS BY RURAL CONSUMER } \\
\text { RESPONDENTS }\end{array}$} \\
\hline & & & \multicolumn{2}{|c|}{ Frequency } & \multicolumn{2}{|r|}{ Percen } \\
\hline \multicolumn{2}{|l|}{ Less than Rs 600} & & \multicolumn{2}{|r|}{440} & \multicolumn{2}{|r|}{27.5} \\
\hline \multicolumn{2}{|l|}{ Rs 601 to Rs 1200} & & \multicolumn{2}{|r|}{432} & \multicolumn{2}{|r|}{27.0} \\
\hline \multicolumn{2}{|l|}{ Rs 1201 to Rs 1800} & & \multicolumn{2}{|r|}{160} & \multicolumn{2}{|r|}{10.0} \\
\hline \multicolumn{2}{|l|}{ Greater than Rs 1800} & & \multicolumn{2}{|r|}{144} & \multicolumn{2}{|r|}{9.0} \\
\hline \multicolumn{2}{|l|}{ Total } & & \multicolumn{2}{|r|}{1176} & \multicolumn{2}{|r|}{73.5} \\
\hline \multicolumn{7}{|c|}{$\begin{array}{l}\text { TRANSFER OF BENEFITS OFFERED BY MARKETERS TO THE RURAL RETAIL } \\
\text { CONSUMERS }\end{array}$} \\
\hline & & & \multicolumn{2}{|c|}{ Frequency } & \multicolumn{2}{|c|}{ Percent } \\
\hline \multicolumn{2}{|l|}{ No } & & \multicolumn{2}{|r|}{832} & & 52.0 \\
\hline Yes & & & & 368 & & 23.0 \\
\hline Sometimes & & & & 400 & & 25.0 \\
\hline Total & & & & 1600 & & 100.0 \\
\hline RURAL CON & ER RES & $\begin{array}{l}\text { NDENT } \\
\text { ERS AN }\end{array}$ & $\begin{array}{l}\text { EMAN } \\
\text { CHEM }\end{array}$ & $\begin{array}{l}\text { FOR SPI } \\
\text { S }\end{array}$ & CIAL BEI & IT, \\
\hline & & & Fre & uency & & Percent \\
\hline No & & & & 168 & & 10.5 \\
\hline Yes & & & & 680 & & 42.5 \\
\hline Sometimes & & & & 384 & & 24.0 \\
\hline Total & & & & 1232 & & 77.0 \\
\hline EXPLANATI & FFERE & $\begin{array}{r}\text { THE I } \\
\text { BEN }\end{array}$ & $\begin{array}{l}\text { AILER } \\
\text { TS }\end{array}$ & FOR NOI & S TRANSF & OF \\
\hline & Exha & & No S & & Date of Of & Expired \\
\hline & $\mathbf{F}$ & $\%$ & $\mathbf{F}$ & $\%$ & $\mathbf{F}$ & $\%$ \\
\hline No & 472 & 29.5 & 408 & 25.5 & 896 & $\overline{56.0}$ \\
\hline Yes & 592 & 37.0 & 656 & 41.0 & 168 & 10.5 \\
\hline Total & 1064 & 66.5 & 1064 & 66.5 & 1064 & 66.5 \\
\hline
\end{tabular}




\begin{tabular}{|l|r|r|r|r|}
\hline & \multicolumn{2}{|c|}{ Not Available in Villages } & \multicolumn{2}{c|}{ Other reasons } \\
\cline { 2 - 5 } & F & \% & F & \% \\
\hline No & 184 & 11.5 & 864 & 54.0 \\
\hline Yes & 880 & 55.0 & 200 & 12.5 \\
\hline Total & 1064 & 66.5 & 1064 & 66.5 \\
\hline
\end{tabular}

\section{Inference:}

The intention of the researcher in constructing this question is to understand the availability of credit by the rural consumer respondents from the retailers for their purchases. Only $26.5 \%$ of the rural consumer respondents state that they do not avail credit, followed by $55 \%$ indicating that they always (yes) buy on credit and $18.5 \%$ indicating that they sometimes use credit facility from the retailer while purchasing the product.

The intention of the researcher in constructing this question is to understand the extent of credit that is availed by the rural consumer for their purchases. $27.5 \%$ of the respondents indicate that the extent of credit that is availed is less than Rs.600, 27\% indicating the level of credit availed is between Rs.601 to Rs 1200 . Only $10 \%$ of the credit availing rural consumers state that the level of credit availed is between Rs.1201 to Rs.1800 and 9\% of them indicated the level of credit availed is greater than Rs. 1800 .

The intention of the researcher in constructing this question is to understand from the rural consumer whether the retailer passes the benefits offered by the companies while purchasing the product to them. $52 \%$ of the rural consumer respondents indicate that they are not being passed with the benefits, $23 \%$ indicating that they always receive the benefits as they are passed on by the retailers and $25 \%$ indicate that they sometimes receive the benefits as they are being passed on by the retailer to the consumer.

The intention of the researcher is to understand the demanding nature of the benefits of the rural consumers who have indicated that they never and sometimes receive benefits that are given by the companies, as they are not passed by the retailer. $42.5 \%$ of the rural respondents who have not been passed with the benefits indicate that they will demand for the offer to be passed on, 24\% indicating that they sometimes demand for the benefits and $10.5 \%$ indicate that they never demand for the passing on the offers that are provided by the companies for the respective products.

The intention of the researcher is to understand the reasons that are offered to the rural consumers by the retailers for not passing on the benefits to them. From preliminary study the researcher has understood that the following are the reasons that are provided by the retailers for not passing off the benefits, viz - offer has exhausted, no stock, date of offer expired, not available in villages and other miscellaneous reasons that the retailer states to the rural consumers. The three common reasons are that the offer is not available in villages with $55 \%$ responses, $41 \%$ indicating that the retailer sights the reason of no stock and $37 \%$ indicating that the benefit that needs to be transferred is exhausted.

\section{TABLE No. 4.7: TEST OF SIGNIFICANCE: DISTANCE TO THE NEAREST TOWN (REMOTENESS) ONNON TRANSFER OF BENEFITS FROM RETAILER}

The intention of the researcher here is to understand the influence of distance to the nearest town of the rural consumer on the transfer or passing of benefits to consumers by the retailers for respective purchases. To understand the significance the researcher constructed the following hypothesis and used a Pearson Chi-Square statistic to prove or disprove the hypothesis.

H0: There is no significant influence of the distance to the nearest town of the rural consumer and the passing of benefits by the retailer to the rural consumers. 
Pearson Chi-Square Tests

\begin{tabular}{|l|l|r|}
\hline \multicolumn{2}{|l|}{} & \multicolumn{2}{|c|}{$\begin{array}{l}\text { Whether the retailer transfers } \\
\text { the benefits offered by the } \\
\text { companies }\end{array}$} \\
\hline \multirow{2}{*}{$\begin{array}{l}\text { Distance to the nearest } \\
\text { town }\end{array}$} & Chi-square & 98.106 \\
\cline { 2 - 3 } & df & 6 \\
\cline { 2 - 3 } & Sig. & .000 \\
\hline
\end{tabular}

Results:

Since the tabulated value of $\chi^{2}$ is 98.106 with 6 degrees of freedom with a significance level of 0.000 which is lesser than the set significance of 0.05 (95\% confidence limit) for tabulated relationship. Therefore, we can reject the null hypothesis

\section{TABLE No. 4.8: TEST OF SIGNIFICANCE: REASONS CITED FOR THE NON TRANSFER OF BENEFITS BY THE RETAILERS}

The intention of the researcher here is to understand the reasons offered by the retailers who are not passing on the benefits to rural consumers. The researcher here goes a step ahead to understand the type of patterns of reasons that the retailer provides to the rural consumer when they not at all pass the benefits and when the retailers sometimes pass the benefits to consumers. To understand the above relationship the researcher constructed the following hypothesis and used a Pearson-Chi-square analysis to prove or disprove the hypothesis.

H0: There is no significant relationship in the reasons offered by occasional and consistent categories of retailers who do not pass benefits to rural consumers.

\section{Pearson Chi-Square Tests}

\begin{tabular}{|l|l|r|}
\hline \multicolumn{2}{|l|}{} & \multicolumn{1}{|c|}{$\begin{array}{c}\text { Explanation of no } \\
\text { transfer of benefits }\end{array}$} \\
\hline \multirow{2}{*}{$\begin{array}{l}\text { Whether the retailer transfers the benefits } \\
\text { offered by the companies }\end{array}$} & Chi-square & 89.949 \\
\cline { 2 - 3 } & df & 5 \\
\cline { 2 - 3 } & Sig. & .000 \\
\hline
\end{tabular}

Result: Since the tabulated value of $\chi^{2}$ is 89.949 with 5 degrees of freedom with a significance level of 0.000 which is lesser than the set significance of 0.05 (95\% confidence limit) for tabulated relationship. Therefore, we can reject the null hypothesis

TABLE No. 4.9:PURCHASE OF FMCG BY THE RURAL CONSUMER RESPONDENTS AT MRP QUOTED

\begin{tabular}{|l|r|r|}
\hline & Frequency & Percent \\
\hline No & 528 & 33.0 \\
\hline Yes & 896 & 56.0 \\
\hline Sometimes & 176 & 11.0 \\
\hline Total & 1600 & 100.0 \\
\hline
\end{tabular}

Source: Field survey

Inference:

The intention of the researcher in constructing this question is to understand whether the rural retailers are selling FMC goods at MRP quoted on the wrapper. The hindsight is also to understand whether the rural consumer respondents observe MRP on the package whenever they purchase a FMCG. From Table it is evident that $56 \%$ of the rural consumer respondents state that they get the products at MRP quoted on the wrapper, $11 \%$ stated that they sometimes receive the FMCG at the price quoted on the wrapper and 33\% stated that they never get the FMCG at MRP 


\section{TABLE No. 4.10: TEST OF SIGNIFICANCE: DISTANCE TO THE NEAREST TOWN (REMOTENESS) ON PURCHASE OF FMCG BY THE RURAL CONSUMER RESPONDENTS AT MRP QUOTED}

The intention of the researcher is to understand whether there is any influence of distance to the nearest town from the rural consumer's village and the chance the rural consumer getting the FMCG at MRP specified on the label or wrapper. In order to understand the significance, the researcher constructed the following hypothesis and used a Pearson Chi-Square test to prove or disprove the hypothesis.

H0: There is no significant influence of distance to the nearest town (remoteness) on purchase of FMCG by the rural consumer respondents at MRP quoted.

Pearson Chi-Square Tests

\begin{tabular}{|l|l|r|}
\hline \multicolumn{2}{|l|}{} & $\begin{array}{l}\text { Do you get the FMCG at the price } \\
\text { is correct, which is quoted on the } \\
\text { wrapper? }\end{array}$ \\
\hline \multirow{2}{*}{ Distance to the nearest town } & Chi-square & 59.542 \\
\cline { 2 - 3 } & df & 6 \\
\cline { 2 - 3 } & Sig. & .000 \\
\hline
\end{tabular}

Results:

Since the tabulated value of the $\chi^{2}$ is 59.542 at 6 degrees of freedom with a significance level of 0.000 which is lesser than set significance of 0.05 (95\% confidence limit) for tabulated relationship. Therefore, we can reject the null hypothesis.

TABLE No. 4.11: REASONS FOR CHARGING EXTRA PRICE

\begin{tabular}{|c|c|c|c|c|c|c|}
\hline & \multicolumn{2}{|c|}{ Local Taxes } & \multicolumn{2}{|c|}{$\begin{array}{l}\text { Extra cost for } \\
\text { Transportation }\end{array}$} & \multicolumn{2}{|c|}{ Low Margin } \\
\hline & $\mathbf{F}$ & $\%$ & $\mathbf{F}$ & $\%$ & $\mathbf{F}$ & $\%$ \\
\hline No & 208 & 13.0 & 552 & 34.5 & 440 & 27.5 \\
\hline Yes & 496 & 31.0 & 152 & 9.5 & 264 & 16.5 \\
\hline \multirow[t]{3}{*}{ Total } & 704 & 44.0 & 704 & 44.0 & 704 & 44.0 \\
\hline & \multicolumn{2}{|c|}{ Slow Moving } & \multicolumn{2}{|c|}{ VAT } & \multicolumn{2}{|c|}{ Others } \\
\hline & $\mathbf{F}$ & $\%$ & $\mathbf{F}$ & $\%$ & $\mathbf{F}$ & $\%$ \\
\hline No & 312 & 19.5 & 600 & 37.5 & 520 & 32.5 \\
\hline Yes & 392 & 24.5 & 104 & 6.5 & 184 & 11.5 \\
\hline Total & 704 & 44.0 & 704 & 44.0 & 704 & 44.0 \\
\hline
\end{tabular}

Source: Field survey

Inference:

The intention of the researcher in constructing this question is to understand the reasons indicated to the rural consumer for not selling the product at MRP. On the hindsight the researcher can also understand the whether the rural consumer is interested to find the reason for the excess of price charged. From preliminary study the researcher has understood the following reasons, viz - local taxes, extra transportation cost, low margin, slow moving, value added tax (VAT) and other miscellaneous reasons, stated as the reasons for pricing more than the MRP. $31 \%$ of the respondents (sometimes and always not able to purchase the FMCG at MRP) indicated that the predominant reason given being local taxes are added, $24.5 \%$ indicating that the FMCG is slow moving and $16.5 \%$ indicating that the reason for selling in excess of MRP is low margin for the retailer.

TABLE No. 4.12: COMPLAINTS AGAINST RURAL RETAILERS

\begin{tabular}{|l|c|c|c|c|c|c|c|c|}
\hline & \multicolumn{2}{|l}{$\begin{array}{c}\text { Wrong Measure } \\
\text { / Weight }\end{array}$} & \multicolumn{2}{|c|}{ Excess Pricing } & \multicolumn{2}{c|}{$\begin{array}{c}\text { Pushes Spurious } \\
\text { Products }\end{array}$} & \multicolumn{2}{c|}{ Old Stock } \\
\cline { 2 - 9 } & F & \% & F & \% & F & \% & F & \% \\
\hline No & 1272 & 79.5 & 896 & 56.0 & 1400 & 87.5 & 728 & 45.5 \\
\hline
\end{tabular}




\begin{tabular}{|c|c|c|c|c|c|c|c|c|}
\hline Yes & 328 & 20.5 & 704 & 44.0 & 200 & 12.5 & 872 & 54.5 \\
\hline \multirow[t]{3}{*}{ Total } & 1600 & 100.0 & 1600 & 100.0 & 1600 & 100.0 & 1600 & 100.0 \\
\hline & \multicolumn{2}{|c|}{ Non Availability } & \multicolumn{2}{|c|}{ Adulteration } & \multicolumn{2}{|c|}{$\begin{array}{c}\text { No } \\
\text { ProductRange }\end{array}$} & \multicolumn{2}{|c|}{ No Discount } \\
\hline & $\mathbf{F}$ & $\%$ & $\mathbf{F}$ & $\%$ & $\mathbf{F}$ & $\%$ & $\mathbf{F}$ & $\%$ \\
\hline No & 784 & 49.0 & 1352 & 84.5 & 1320 & 82.5 & 1448 & 90.5 \\
\hline Yes & 816 & 51.0 & 248 & 15.5 & 280 & 17.5 & 152 & 9.5 \\
\hline \multirow[t]{3}{*}{ Total } & 1600 & 100.0 & 1600 & 100.0 & 1600 & 100.0 & 1600 & 100.0 \\
\hline & \multicolumn{2}{|c|}{$\begin{array}{c}\text { Less Product } \\
\text { Mix }\end{array}$} & \multicolumn{2}{|c|}{$\begin{array}{l}\text { No Credit } \\
\text { Facility }\end{array}$} & & & & \\
\hline & $\mathrm{F}$ & $\%$ & $\mathrm{~F}$ & $\%$ & & & & \\
\hline No & 1392 & 87.0 & 1536 & 96.0 & & & & \\
\hline Yes & 208 & 13.0 & 64 & 4.0 & & & & \\
\hline Total & 1600 & 100.0 & 1600 & 100.0 & & & & \\
\hline
\end{tabular}

Source: Field survey

\section{Inference:}

The intention of the researcher in constructing this question is to understand the complaints that the rural consumers articulate against the rural retailers. From preliminary study the researcher has understood the following as the reasons that need to be included in the questionnaire, viz - wrong measure or weight, excess pricing, pushes spurious products, old stock, non-availability, adulteration, no product range, no discount, less product mix and no credit offered to consumers. From Table No.4.12 it is evident to the researcher that $57.5 \%$ of the respondents stated that excess pricing, $54.5 \%$ stating old stock, $51 \%$ indicating non availability of a particular product, $20.5 \%$ indicating wrong weight or measure and $17.5 \%$ indicating no product range. $15.5 \%$ of the rural consumers state that the rural retailer adulterates the product and $12.5 \%$ of the rural consumers indicated that the rural retailer pushes spurious product.

\section{THE FACTORS OF INFLUENCE IN THEIR PREFERENCE FOR A PARTICULAR RETAIL OUTLET WHERE THEY SHOP.}

The intention of the researcher in constructing this regression equation is to understand the perspective of the rural consumer respondents on the factors of influence in their preference for a particular outlet where they shop. The researcher from preliminary study of the rural consumers have understood the importance of the following factors, viz - credit facilities, reasonable price, personal rapport with the retailers, good service and nearness pertaining to the outlet, which influence the rural consumers' preference. In order to understand the major determinant or determinants to influence in their preference for a particular outlet where they generally shop, a multiple regression analysis was performed to test the hypothesis. The following multiple regression model has been used to test the theoretical relationship between the above mentioned factors and the choice of a particular shop.

$Y($ Choice of a specific retail outlet $)=a+b_{1} X_{1}$ (Credit facilities $)+b_{2} X_{2}$ (Reasonable Price $)+b_{3} X_{3}$ (Personal rapport with the retailers) $+b_{4} X_{4}$ (Good Service and Quality products) $+b_{5} X_{5}$ (Nearness) $+\epsilon$

Where,

$Y=($ Choice of a specific retail outlet $)$

$X$ is the vector of explanatory variables in the estimation model

$X_{1}=$ Credit facilities

$X_{2}=$ Reasonable Price

$X_{3}=$ Personal rapport with the retailers

$X_{4}=$ Good Service and Quality products

$X_{5}=$ Nearness

$a=$ constant intercept term of the model 
$b=$ coefficients of the estimated model

$\epsilon=$ error component

TABLE No. 4.13

REGRESSION RESULTS

\begin{tabular}{|c|c|c|c|c|c|c|}
\hline & & & & & Collinearity & itics \\
\hline & Coefficients & $\begin{array}{l}\text { Standard } \\
\text { Error }\end{array}$ & $t$ Stat & $P$-value & Tolerance & VIF \\
\hline Constant & 23.7621 & 6.4756 & 3.6695 & 0.0350126 & & \\
\hline $\mathrm{X}_{1}$ & -7.8870 & 1.3599 & $\mid-5.7998$ & 0.0102 & .523 & 2.371 \\
\hline $\mathrm{X}_{2}$ & -15.0337 & 4.8993 & -3.0685 & 0.7546 & .633 & 1.998 \\
\hline $\mathrm{X}_{3}$ & -0.6439 & 0.1909 & -3.3727 & 0.6433 & .845 & 1.764 \\
\hline $\mathrm{X}_{4}$ & -5.4823 & 1.6197 & -3.3848 & 0.0429 & .656 & 1.921 \\
\hline $\mathrm{X}_{5}$ & 0.0028 & 0.0009 & 3.0260 & 0.0465 & 931 & 1.314 \\
\hline
\end{tabular}

TABLE No. 4.14MODEL SUMMARY

\begin{tabular}{|c|c|c|c|c|c|c|}
\hline R & R Square & $\begin{array}{l}\text { Adjusted } \\
\text { R Square }\end{array}$ & $\begin{array}{l}\text { Std. Error of the } \\
\text { Estimate }\end{array}$ & $\begin{array}{l}\text { Durbin- } \\
\text { Watson }\end{array}$ & F Value & Sig. \\
\hline 0.9864 & 0.9730 & 0.9189 & 0.1459 & 1.930 & 12.7840 & 0.0305 \\
\hline
\end{tabular}

Intercept is $\alpha$ in the set equation. Standard error measures the variability in approximation of the coefficient and lower standard error means coefficient is closer to the true value of the coefficient. Result shows that $\mathrm{X}_{2}$ (Reasonable Price) and $\mathrm{X}_{3}$ (Personal rapport with the retailers) are not statistically significant; However, $\mathrm{X}_{1}$ (Credit facilities), $\mathrm{X}_{4}$ (Good Service and Quality products) and $\mathrm{X}_{5}$ (Nearness) are statistically significant at $5 \%$ level of significance.

It is evident from table No. $4.14 \mathrm{R}$-square value of 0.9730 (with an adjusted $\mathrm{R}^{2}$ of 0.9189 ) indicating that $97.30 \%$ of the information of dependent variable is predicted by the model. However, in all, $\mathrm{X}_{1}$ (Credit facilities), $\mathrm{X}_{4}$ (Good Service and Quality products) and $\mathrm{X}_{5}$ (Nearness) are highly significant. $F$ test indicates the fitness of the model. The above table No 4.14shows that (ANOVA) suggests that model is statistically significant with F value (12.7840) at a significance level of 0.0305 . When it comes to collinearity statistics VIF values score ranges in between1.314to 2.371indicating that was not a problem.

\section{DISCUSSION AND CONCLUSION}

The current study has been undertaken to investigate the stores' loyalty of the rural consumers, the major factors that determine the preference of a particular retail outlet, the nature of the suggestions sought by the rural consumers from the retailers before buying FMCG and to find out whether the rural retailer transfer of benefits offered by marketers to the rural consumers. In order to realise the stated objectives the researchers have collected the data from 1,600 rural consumers from 200 villages across the four zones of the Karnataka state. The validity of the research instrument was adjudged, using reliability statistics, Cronbach alpha coefficient. Cronbach's coefficient $(\alpha)$ was calculated to test the reliability and internal consistency of the responses. Cronbach's coefficient, having a value of more than 0.7 is considered adequate for such exploratory work. The values of $\alpha$ in this study for the reported questions were found to be $0.736,0.805,0.765$ etc. giving an average value of 0.768 . It implies that there is a high degree of internal consistency in the responses to the questionnaire. Later the collected data was collated by using SPSS software. The study revealed that majority of the rural consumer respondent purchases their entire FMCG requirement in one shop. 32.5\% of the rural consumers attribute that the retail outlet where they shop is able to provide fresh stock, $25 \%$ always get fresh stock, $24.5 \%$ rarely get fresh stocks, $17 \%$ get fresh stock only sometimes and $1 \%$ never get fresh stock in the retail outlet they shop. $38.5 \%$ attributed the predominant factor being the availability 
of credit, 33\% personal rapport with the shop keeper (rank 2), $16 \%$ price (rank 3), 36.5\% good service (rank 4), and $40 \%$ proximity of the retail outlet (rank 5). There is a significant difference in the factors among the rural consumer respondents that lead to the preference of a particular retail outlet. There is a significant influence of distance to the nearest town on the rural consumer purchasing the entire FMCG requirement in same shop. There is a significant influence of annual house hold income on the rural consumer purchasing the entire FMCG requirement in same shop.66\% of the rural consumers seek clarification (case-on-case basis) from the retailer before purchasing the product, $8 \%$ always clarify before purchasing from the rural consumer and $26 \%$ do not seek suggestions from the retailer. $61 \%$ of the rural consumer respondent's clarification is regarding the quality of the product, $44.5 \%$ regarding special offers, $40 \%$ indicating price, $33 \%$ indicating suitability of the need of the product, $21.5 \%$ clarifications regarding alternative brands while switching and $21 \%$ regarding the usability nature of the product. There is a significant difference in the nature of clarification made by the rural consumer to the retailer. Only $26.5 \%$ of the rural consumer respondents do not avail credit, 55\% always (yes) buy on credit and $18.5 \%$ sometimes use credit facility. $27.5 \%$ of the respondents avail credit less than Rs.600, 27\% indicating the level of credit availed is between Rs.601 to Rs 1200, 10\% avail credit between Rs. 1201 to Rs. 1800 and 9\% availing credit greater than Rs. $1800.52 \%$ of the rural consumer respondents state that they are not being passed with the benefits, $23 \%$ state that the benefits are passed on by the retailers and $25 \%$ state that they sometimes receive the benefits. $42.5 \%$ of the rural consumer respondents who have not received the benefits indicate that they will demand for the offer to be passed on, 24\% sometimes demand for the benefits and $10.5 \%$ never demand for the offers that are provided by the companies for the respective products.55\% of the rural consumer respondents state that offer is not available in villages, $41 \%$ providing the reason of no stock and $37 \%$ articulate that the offer is exhausted. There is a significant influence of the distance to the nearest town of the rural consumer and the passing of benefits by the retailer to the rural consumers. There is a significant relationship in the reasons offered by occasional and consistent categories of retailers who do not pass benefits to rural consumers.56\% of the rural consumer respondent pays for the purchases of the products at MRP quoted on the wrapper, $11 \%$ sometimes receive the FMCG at the price quoted on the wrapper and 33\% never get the FMCG at MRP. There is a significant influence of distance to the nearest town from rural consumer's village on the consumer purchasing the FMCG at MRP. $31 \%$ of the rural retail respondents state the reason given as local taxes added, $24.5 \%$ slow moving nature of FMCG and 16.5\% state low margin provided by FMCG companies.57.5\% of the rural consumer respondents state excess pricing, $54.5 \%$ old stock, $51 \%$ non-availability of a particular product, $20.5 \%$ wrong weight or measure and $17.5 \%$ no product range, $15.5 \%$ adulteration of the product and $12.5 \%$ pushes spurious product. Regression results revealed that $\mathrm{X}_{1}$ (Credit facilities), $\mathrm{X}_{4}$ (Good Service and Quality products) and $\mathrm{X}_{5}$ (Nearness) were the major determinants of the stores choice. It had a very high R-square value of 0.9730 indicating that $97.30 \%$ of the information of dependent variable is predicted by the model. On the background of the above summary of findings the following suggestions have been offered to the FMCG marketers.

It is observed that $57.2 \%$ of the retailers in interior villages charge more than the MRP quoted on the packets. They justify overcharging by pointing out to the fact that they spend time and money to fetch the products from the nearest feeder towns. This in turn suggests that retailers in rural markets seek higher margins as compensation for transportation costs incurred and less movement of the product. This inference is supported as it is observed that festival discounts and other offers given by the manufactures to retailers normally contribute to increase in stock levels in the shops. These concessions are almost never passed on to consumers because of the greed of retailers. Another interesting observation made by the researcher is that consumers rarely demand promotional offers, excepting village youth and children. Therefore, the retailers should be motivated to pass on the benefits offered by the marketers. The entire promotional campaign communications should be targeted towards village youth and children because most of the time only this group demands schemes and offers.

For rural products, the strategies adopted must focus on cutting the middlemen margins; reducing frills and keeping lower stocks to reduce transaction costs and passing these benefits to customers can further increase the turnover. Therefore, it is suggested that marketers use urban markets for value and 
rural markets for volume to achieve trade-off between value and volume. Alternative to this "direct consumer" strategy, traveling "sales force" can also be incorporated to pass the benefits to the consumers. Keeping in view the seasonality and low disposable income of the rural consumers, penetration pricing will undoubtedly be very effective.

The data on rural consumer buying behaviour highlights the fact that "the rural retailer influences 35 per cent of all purchase decisions" (NandiniLakshman 2003). In the words of Lahiri;Suri (2003)the rural consumers interact directly with their retail salespersons who have a strong conviction power and whose recommendations carry weight. The owners' relationship with customers is based on an understanding of their needs and buying habits and is cemented by the retailer extending credit. For this reason of control and better understanding of the rural consumers, an increasing number of corporates are setting up retail outlets in small towns and rural markets in order to reach out to the large untapped consumer base (Kala \& Paul 2005). According to Mohan Agrawal (2003), attracting customer to these retail outlets is an essential marketing activity. The quickest way to offer customer value is through promotional pricing at retail points. Apart from this scale of operations, most of these retail outlets are usually small. These retailers are not able to carry stocks without adequate credit facility. Unless institutional credit is provided, it is very difficult task for the marketer to sell the products on credit basis to such a large number on national scale (Narasimham1995).

In the background of the current empirical study, the researchers have identified the following areas for future research which can be carried in the field of rural marketing. First, the current study was conducted only on a sample size of 1,600 rural respondents and was confined to geographical limits of Karnataka state only, therefore, the results obtained may not be pertinent to the country as a whole. Hence, it is recommended to conduct an extended study of this kind encompassing more number of states (to capture to cultural differences across regions) and larger sample size may be taken up. Furthermore, research can be carried out about organized retail outlets and its impact on the buying behavior of rural consumers.

\section{REFERENCES}

[1] Adelina Broadbridge, Eric Calderwood, (2002). "Rural grocery shoppers: do their attitudes reflect their actions?" International Journal of Retail \& Distribution Management, Vol. 30 Issue: 8, pp.394 - 406

[2] Ajita Shashidhar (2003). "Colas' countryside crusade", The Hindu Business line, Catalyst - Rural Marketing, Thursday, July 03.

[3] Anuradha Devadas and Hansa Lysander Manohar (2010). "Shopping behavior of rural consumer migrated to urban area in the Indian context - An emerging market". African Journal of Business Management.Vol. 5(6), 18 March, pp. 2276-2282.

[4] Dash, Joseph F., Schiffman, Leon G., and Berenson Conrad (1976). "Risk and Personality-Related Dimensions of Store Choice", Journal of Marketing, Vol. 40, January, pp. 32 - 39.

[5] Dodge, H. Robert, Summer, Harry H. (1969), “Choosing Between Retail Stores”, Journal of Retailing, Fall, Vol. 45, No.3, pp. $11-21$.

[6] Erdem, Orhan, Oumlil A. Ben and Tuncalp Secil (1999)., "Consumer Values and the Importance of Store Attributes", International Journal of Retail and Distribution Management, Vol. 27, No. 4, pp. $137-144$.

[7] Fotheringham, A. Stewart. (1988), "Consumer Store Choice and Choice Set Definition", Marketing Science, summer, Vol. 7, No. 3, pp. $299-310$.

[8] Hisrich, Robert D., Dornoff, Ronald J., and Kernan, Jerome B (1972). "Perceived Risk in Store Selection", Journal of Marketing Research, November, Vol. IX, pp. 435 - 39. 
[9] Kahn B and Schmittlein D D (1989). "Shopping Trip Behaviour: An Empirical Study", Marketing Letters, Vol. 1, No. 1, pp. 55 - 69.

[10] Kala Vijayraghavan and Cuckoo Paul (2005). "India, Inc. tunes in to country music", The Economic Times, Wednesday, August 10.

[11] Kenhove, Patrick Van, Wulf, Kristof De and Waterschoot, Walter Van (1999). "The Impact of Task Definition on Store-Attribute Saliences and Store Choice", Journal of Retailing, Vol. 75, No. 1, pp.125-137.

[12] Leszczyc, Peter T.L. Popkowski., Sinha, Ashish,Timmermans, Harry. J.P (2000). "Consumer Store Choice Dynamics: An Analysis of the Competitive Market Structure for Grocery Stores", Journal of Retailing, Vol. 76 (3), pp. $323-345$.

[13] Lumpkin, James R., Greenberg, Barnett A., and Goldstucker, Jac. L. (1985). "Marketplace Needs of the Elderly: Determinant Attributes and Store Choice", Journal of Retailing, Summer Vol. 61, No.2, pp. $75-105$.

[14] Mattson, Bruce E. (1982), “Situational Influences on Store Choice”, Journal of Retailing, Fall, Vol. 58, No. 3, pp. $46-58$.

[15] Minouti Kamat and R. Krishnamoorthy. (2003), "Rural Marketing”, Himalaya publishing House, Mumbai, pp. 4-5.

[16] Mohan Agrawal. (2003), "Re attracting retail customers- an argument for promotional pricing", Prayaas (the endeavor), The International Journal of Business Management, Vol. IV, July, pp. 2-8

[17] Mukunda Das V, Somanath Sen. (1991), "Community clout -the rural way", A\&M, September, pp. 6667.

[18] Mukunda Das V, Somanath Sen. (1991), "Missing the point" -the rural way, A\&M, July, pp. 22.

[19] N. V. Narasimham. (1995), "Rural markets- features and marketing strategies", Indian Journal of Marketing, Vol. XXIV, No. 11-12, November- December.

[20] NandiniLakshman. (2003), “India Inc eyes rural markets”, Business Standard, October25,

[21] NavinMathur. (1976), “Rural Marketing”, Indian Journal of Marketing, Vol. 4, pp. 3.

[22] Pradeep Kashyap. (2003), “Revolution-in-waiting” Praxis- Business line-Theme, July, pp 6-11

[23] Richa Mishra (2003). "LG bets on economy range, infrastructure to tap rural market", The Hindu Business line, October 04.

[24] RinkuPegu. (1999), “Maya bazaar”, The week, May 30,

[25] Rohini Gupta Suri. (2003), "Rural markets-some issues", Indian Journal of Marketing,Vol XXXIII, No.10, October, pp. 22-24.

[26] SampaChakrabartyLahiri., "Strategic Issues -A Peek into the rural market", www.etstrategicmarketing.com/smJune-July2/art6_1.htm - 63k - Cached - Similar pages

[27] Sathyanarayana S andRamani Ganesh. (2008), "Rural Retail Management", Journal of Contemporary Research in Management, July - Sep pp. 81-99.

[28] Sathyanarayana S. (2011). "Trends in the marketing of FMCGs in Karnataka state", DharanaBhavan's International Journal of Business. Vol. 5, 1\&2 (Jan-June). ISSN 09740-0082, pp. 61-73 
[29] Sathyanarayana S. (2014). "The role of spurious products in rural retailing-A study", DharanaBhavan's International Journal of Business. Vol. 8, No. 1 (Jan-June). ISSN 09740-0082, pp. 11-21.

[30] Satish P. Rewatkar (2013). "Concern for branding and occupation in rural Maharashtra" (With reference to food and grocery segment of FMCG). International Journal of Application or Innovation in Engineering \& Management (IJAIEM). Volume 2, Issue 12, December, pp. 358-360.

[31] Stanly C. Hollander. (1960), “The wheel of retailing”, Journal of Marketing. July, pp. 37-42.

[32] SurajitDey, SameenaRafat and Puja Agarwal (2012). "Organized Retail in the Rural Markets in India". IOSR Journal of Business and Management (IOSR-JBM). Volume 6, Issue 1 (Nov. - Dec. 2012), pp. $16-25$

[33] Woodside, Arch G., and Trappey, III, Randolph J. (1992), "Finding out Why Customers Shop Your Store and Buy Your Brand: Automatic Cognitive Processing Models of Primary Choice", Journal of Advertising Research, Nov. Dec, pp. $59-78$. , "Offer products to suit rural markets", The Hindu, Saturday, October 06, 2001.

[35] __ _Rural markets: Long haul, but big opportunities", India Post News Service, http://www.indiapost.com/new_ip/members/story.php?story_id=1273, Published on 27-08-2002, Date of download 8-03-2004.

[36] _ _Changing trends in retainlg and FMCG industry in India", http://icmr.icfai.org Mini Case Code: CLBS019, Publication date: 2004, Subject: Business Strategy, Industry: Retail. 